\title{
Kafka and Deleuze/Guattari: Towards a Creative Critical Writing Practice
}

In what does writing begin?

What is it that prompts a writer, that instigates within her, an urge to write? In a time informed by cultural studies, social histories of art and deconstruction, this may seem a somewhat archaic question, but it is, significantly, one to which Deleuze and Guattari return at several instances, not least in Kafka: Toward a Minor Literature (1986). Their answer, it seems to me, is to be found in Kafka's encounter with an entire structure or set of impossibilities lodged within the historical and socio-political context from within which his writing emerged.

In the third chapter of the above book, referencing one of Kafka's letters to Max Brod, Deleuze and Guattari provide an initial outline of a tripartite structure of impossibilties: 'the impossibility of not writing, the impossibility of writing in German, the impossibility of writing otherwise' (Deleuze and Guattari, 1986: p. 16). The entire chapter centres around this tripartite impossibility, the 'otherwise' of which is later developed in reference specifically to Yiddish and Hebrew (Deleuze and Guattari, 1986: p. 25). It is not, however, in relation to language alone, that the structure of impossibilities is deployed in the book. Throughout the fourth chapter, this structure is developed in terms of the impossibility of the conjugal contract, the impossibility of movement (Kafka's is stuck in his room, in his bed, in his coffin), the impossibility of the becomings-animal, the impossibility of finishing the interminable novels (Deleuze and Guattari, 1986: pp. 30, 36-37). An overwhelming set of impossibilities, akin to paralysis, from which it appears nothing will ever be able to liberate itself. Yet it is precisely from within this set of impossibilities that Kafka's writing seems to emerge and it is from subsequent impossibilities that it mutates and changes form. From the tripartite impossibility of language emerges an impoverished German as a line of flight (Deleuze and Guattari, 1986: p. 26); from the impossibility of the conjugal contract and of movement emerges the epistolary component of Kafka's writing, the letters doubling the subject of enunciation in the subject of the statement allowing for an escape route to open up (Deleuze and Guattari, 1986: p. 30); from the botched deterritorializations of the becomings-animals of the stories emerges the machinic assemblages of the interminable novels (Deleuze and Guattari, 1986: pp. 36-37). It is as if an entire writing practice comes out of the encounter with impossibility; one which doesn't recognize literary genres or formats but proceeds through assemblages of fragments, false starts, botched becomings, and the proliferation of interminable lines of flight. ${ }^{i}$

How are we to undertstand this notion of impossibility, seemingly so significant to Deleuze and Guattari's conception of writing? Certainly, it's not implicit to writing that it emerges from a set of impossibilities. Writing can begin elsewhere. In 1979, four years after the publication of Kafka: Toward a Minor Literature, Guattari discusses this awkwardly phrased question - in what does writing begin? - in an interview with George Stambolian. Says Guattari,

\footnotetext{
Writing begins to function in something else, as for example for the Beat Generation in the relation with drugs; for Kerouac in the relation with travel, or with mountains, with yoga. Then something begins to vibrate, begins to function. Rhythms appear, a need, a desire to speak. Where is it possible for a writer to start this literary machine if it isn't precisely outside of writing and of the field of literature (Guattari, 1996a: p. 209).
}

There are a few terms in this citation to which we must pay extra attention: relation, vibration and function. Writing, for Guattari - and this notion certainly occurs also in his joint work with Deleuze - is a machine with a set of components and functions. It involves the writer-subject, the fingers, the hand, the breath, but also the pen or pencil, the typewriter or word processor, the paper, and the material that is language itself. This makes of writing a machinic agencement (or 'assemblage,' see Guattari, 1995b) but it is one that in order to be set in motion requires an encounter with what is outside the field of literature: drugs (Burrough's opiates, Kerouac's Benzedrines), travel (Kerouac's mountain, 
Burrough's Tangiers), other technologies (Burrough's and Beckett's tape recorders). It is my proposal, that we add Kafka's encounter with an overwhelming set of impossibilities to this list. In my reading, it is from these encounters, that a writing machine begins to function, and it is from the encounter with an impossibility to write, in Kafka's case, that a need, a desire to write emerges as yet another impossibility, an impossibility not to write, rendering his predicament more profound but liberating, at the same time, a potential - a vibration, a function - setting his writing machine in motion.

What, then, constitutes such an encounter? In the introduction to his book Art Encounters Deleuze and Guattari, Simon O'Sullivan situates the encounter in direct opposition to recognition. An object of recognition, he proposes referencing Deleuze's Difference and Repitition, reconfirms our habitual ways of understanding and being in the world, whereas an object of encounter, disrupts such habitual modes of thought and action, opening up, instead, to the affirmation of a 'way of seeing and thinking this world differently' (O'Sullivan, 2006: p. 1). To O'Sullivan this is a creative moment, perhaps the creative moment. Certainly, I am inclinded to agree, although we need to proceed a little more cautiously to grasp the relevance of this notion when it comes specifically to writing. To do so, I would like to return, briefly, to those three components of the encounter, hinted at by Guattari in the interview cited above: relations, vibrations, functions.

To fully grasp what Guattari has in mind when he speaks of the encounter within which writing begins to function, we need to first consider the notion of affect, so central to the Spinozism that runs as a torrent through Deleuze and Guattari's work. An affect, to Deleuze and Guattari's Spinoza, is essentially a becoming, a body's passage from one affection to another. Whereas an affection designates a body's state at a particular moment in time, an affect designates a passage between states; that is, a body's becoming-other to itself, its potential for differentiation (Deleuze, 1988: pp. 48-51). These passages, however, do not open up in a vacuum. They are the result of the material interaction of bodies in complex sets of relations; simple bodies forming compound bodies of ever greater complexity. These bodies continuously affect one another (see, for instance, Spinoza, 2002, pp. 251-255). This is a concept of the body that is molecular (compound bodies consist of constellations of simple bodies and form part of more complex bodies) and in continuous becoming (a compound body can be relatively stable, but it remains temporal and in flux).

Now, to Spinoza these passages, or affects, can either increase or decrease a body's capacity to act. Such passages between degrees of capacity is conceived of by Spinoza as increases and decreases in the speed of a body. An affect, in other words, is an increase or decrease in speed where greater velocities correspond to greater capacities (Spinoza, 2002: pp. 252-253, 255, 278-279). This is certainly foregrounded in Deleuze's Spinoza: Practical Philosophy (1988) but also in Deleuze and Guattari's joint work A Thousand Plateaus (1988) in which a body is defined as nothing but 'affects and local movements, differential speeds' (Deleuze and Guattari, 1988: p. 261). It is precisely on the basis of this link between speed and capacity we need to understand Guattari's notion of 'vibration;' an affective encounter alters the constellation of speeds, but also slownesses, that compose a body. It produces a vibration, or better perhaps, it causes a body to vibrate differently, in a different rhythm. ${ }^{\text {ii }}$

Spinoza's molecular universe consists entirely of such bodies, in motion or at rest, forming and unforming compound bodies continuously shifting. The human body is one such complex of compound bodies affecting one another, temporarily held together and continuously affected by and affecting external bodies of different kinds (Spinoza, 2002: pp. 251-255). On the basis of this notion of affect, Spinoza builds an entire epistemology - our knowledge of the world, the notions we form, they can only be formed on the basis of the affects that compose our body - as well as an ethics inexorably linked with a political project configured around our ability to distinguish between affects that decrease our capacity to act - perceived as 'sadness' - and those that increase our capacity to act - perceived as 'joy.' Spinoza's ethico-politics is grounded entirely in the programs we establish to seek out the affects that cause us joy rather than those that cause us sadness. ${ }^{\text {iii }}$ 
This Spinozism is central to Deleuze and Guattari's whole project, yet the link to aesthetics, and to writing specifically, remains somewhat vague. What configuration of affects - what increases and decreases in speed - make up an encounter capable of setting a writing machine in motion, or in other words, capable of making it function?

Certainly, not all encounters are creative, or better, aesthetic, encounters. To say that certain encounters produce the conditions necessary for a writing machine to be set in motion requires of us to make distinctions between encounters of different orders akin but not analoguous to Spinoza's ethical distinction. In fact, it would be of little use to say that writing follows the programmatic principle of a Spinozist ethico-politics. Nor would it be useful to say that the encounters that prompt us to think are necessarily the same as those that set a writing machine in motion.

From a Spinozist perspective, the complexity of the human body means it is continuously affected. An affect is not a rare, unexpected event. It is the stuff of life. As we pass from affection to affection, a great number of affects alternately increasing and decreasing our speed and capacity - forms the passages of our becoming (Spinoza, 2002: pp. 25-255). Kafka's impossibility has do with a complex constellation of affects leaving him close to paralysis, an overwhelming encounter that produces a particular kind of writing proceeding through the peculiar assemblage that is Kafka's body of work; Burrough's encounter with drugs sets in motion a writing machine or assemblage that involves heroin but also typewriters, cities and needles, and Kerouac's encounter with the mountain sets in motion a writing machine that involves that mountain itself, but also hodologies, solitude and meditation. Again, these encounters involve entire registers of affects that together make up the encounter. What Spinoza calls forth, if we are to read an aesthetics into Spinozism, is a micro-physics of affects opening up to an experimentation with the diverse affectconstellations that make up an encounter.

Such a micro-physics of affect-constellations may involve less spectacular encounters than those Deleuze and Guattari hint at. Writing this, on the desk in front of me, I have a series of black and white images of boarded up windows and bunsen burners on a wooden floor. These images - an encounter with Jannis Kounellis' work - have been incredibly significant to me. Yet, there is nothing about the mute materiality of these works that I understand. They slip and slide beneath any attempt at interpretation. In a way, they resist understanding, offering instead an entirely expressive register of affects. Similarly, a few years ago, at a camp site in Erfurt, I listened to a recording of Kristen Prevallet reading at the Bowery Club in New York City. In her reading, she is taking a US presidential statement on the conflict in Iraq, repeating it and replacing, in each repetition, the words of the original statement with the word 'oil.' As she repeats the word 'oil' in her performance of the text, however, her speech mechanism fails her - the movement of tongue, the flow of air, the synchronized movements of the lips, the twists required - and she loses her grip on the prosodies, the rhythms of the repetition. She stutters. The stutter has nothing to do with the conceptual nature of the poem, with its political theme, or with the volition of the writer-performer. At the moment of the stutter, something else occurs. There is a break in the predictable pattern of repetitions. Not so much a cessation or a slowing down as a series of blockages interrupting the flow but creating, also, another flow, a deviance. In this deviance lies the laughter of the audience. Although it may appear malicious to an outside observer or listener, I would like to think it wasn't so at all. On the contrary, it seems to me to have been an entirely involuntary laughter - shared, common - originating deep inside the deviance, in the deviant turn, in the deviant affect, opening the syntactical economies of language up to a series of radiantly joyful excesses and transgressions. It is the encounter with the stutter, the affect of the stutter, that expresses itself and causes the audience to express itself in laughter.

Boarded up windows, bunsen burners, stuttered poetry. It is important, however, to note that even though writing begins in the encounter, in a micro-physics of affects, this in no way implies that writing is biographical or that it is situated within biography. It is not even to say that it is situated, strictly speaking, in the writer as a subject. Much rather, it begins in a liminal space outside the subject; that is, in the prepersonal affects that make up the encounter. Deleuze was very clear about this, albeit in a later essay, where he claims that to write, 'is certainly not to impose a form (of expression) on the matter of lived experience. [...]. Writing is a question of becoming, and goes beyond the matter of 
any livable or lived experience. It is a process, that is, a passage of Life that traverses both the livable and lived' (Deleuze, 1998: p. 5). ${ }^{\text {iv }}$ I shall return to this question. Suffice at this stage to say that writing begins in the prepersonal affect-constellations of an encounter, but in contrast to a Spinozist ethico-politics, however, writing then follows a somewhat different trajectory; an aesthetic one. A writer may live an ethical life, and an ethical life is inexorably linked both to thought and politics, but it is not an ethical trajectory that writing follows. It is an aesthetic one. These trajectories may interesect at certain points. They may form a weave through a writer's life, but they cannot be reduced one to the other. An ethical trajectory exclusively involves an affirmation of increasing speeds and capacities; or in other words, the programmatic distinction between joy and sadness. An aesthetic trajectory, on the other hand, has little to do with such programmatic distinction between affects. Much rather, it has to do with an experimentation with affectconstellations of different kinds; with an openness and an attentiveness to chance; with excess and transgression, or with boredom and solitude; with very low velocities, or with very high speeds; with exhilarations, or with stillness; whatever allows a writer to remain open to the unexpected, to ruptures and encounters that in some way cause her to overcome her sense of self. It would be more correct to say that aesthetics work to contaminate an ethico-political program; at times opening up to unexpected new horizons, alliances and affiliations that are in line with an ethical program, at other times, to botched attempts, silences, boundless transgressions, weakness, exhaustion, even death. ${ }^{\mathrm{v}}$ This is an aesthetic we have to read into Spinoza, and more particularly, into the use Deleuze and Guattari makes of Spinoza; an experimentation with the forms of experience - a life lived creatively - that lodges creative writing, at its inception, not in life in its biographical sense but in life in its prepersonal sense, as the capacity for differentiation, for life becoming-other, foreign to itself.

How does one begin to write?

An encounter, a vibration, a rhythm. But a desire to write is not in itself writing. Something is clearly set in motion, but it is not yet writing. How does one begin to write? To Deleuze and Guattari, this seems to be a twofold question: First, writing requires an architecture, and second, writing requires an expression without content.

Spatiality, topography and architecture are central preoccupations of Deleuze and Guattari's. They form, in many ways, a thematic that runs through most of their work, and it is certainly crucial to their understanding of artistic practice, including creative writing. This becomes very clear in their final co-authored work, What is Philosophy? 'Art begins,' they write, 'with the house. This is why architecture is the first of the arts' (Deleuze and Guattari, 1994: p. 186). Now, this is not merely to say that architecture is prior to all other arts, it is to say that architecture is prior within all other arts; that is, what is required is an architecture at work within writing. Think, for instance, of the great architectures of Kafka, or those of Proust, to mention two writers of whom Deleuze and Guattari are particularly fond. Or think of Beckett's Molloy and his relationship to his mother's room, so central to the novel. Or, to move away from those that Deleuze and Guattari admired and wrote about, the distinct dystopian architectures that are always at work in J. G. Ballard or Philip K. Dick's writing. However, it is not enough to say that writing contains an architecture - it significantly also proceeds, at first, as architecture. Elizabeth Grosz discusses this at some length in her book Chaos, Territory, Art: Deleuze and the Framing of the Earth. 'Art is first architectural,' she writes, 'because its [...] materials require demarcation, enframement, containment in order for qualities as such to emerge, to live, and to induce sensation' (Grosz, 2008: p. 16). Art requires enframement and demarcation, and writing too, requires its specific architecture, what Deleuze and Guattari refers to as a 'plane of composition,' an ordering of materials into a spatiotemporal construct. This already features an architectonic, a design of frames that constitutes a space - indeed, even a shelter - from chaos, and from this follow more complex constructions of interlocked frames and planes.

[The] wall that cuts off, the window that captures or selects $[\ldots]$ the ground-floor that wards off or rarefies $[\ldots]$ the roof that envelops the place's singularity [...]. Interlocking these frames or joining up all these planes - wall section, window section, floor section, slope section - is a composite system rich in points and counterpoints (Deleuze and Guattari, 1994: p. 187). 
The plane of composition is the beginning, then, of both the territory and the house, the soil and domesticity, culture and economy. However, it is not static. On the contrary, the plane of composition is constantly being drawn, opened up and closed off. Irrespective of the extendability of an architecture, Deleuze and Guattari writes, 'it still needs a vast plane of composition that carries out a deframing following lines of flight that pass through the territory only to open it onto the universe' (Deleuze and Guattari, 1994: p. 187). Writing needs an architecture for affects to emerge, but also so that passages open up - not least to what is non-architectural. We see a familiar DeleuzoGuattarian topography deployed here: planes, frames, territories; territorializations, deterritorializations, reterritorializations; the soil, the house, the line of escape. This is the topography of the encounter from within which writing begins, but it is also a topography that writing, in turn, needs to set up.

This notion of spatiality is crucial to writing, but also to philosophical thought. A space needs to be delineated for thought to become other to itself. It is not, however, the same spatial architecture as that which writing opens up and closes off for itself. This distinction is significant as it speaks to the differences and relations between philosophical thought and artistic practice in Deleuze and Guattari's work. Whereas writing requires an architecture of planes and demarcations, enframement and containment, something else is being drawn up in philosophy, an architecture more akin to the dramatic. Already in 1968, in Difference and Repetition (1994), Deleuze introduced such notion of spatiality into philosophy, not a philosophy of space, but a spatiality carved out within philosophy. Interestingly, the spatiality he refers to in this text, is that of theatre. '[Something] completely new begins with Kierkegaard and Nietzsche,' he writes. 'They invent an incredible equivalent of theatre within philosophy, thereby founding simultaneously this theatre of the future and a new philosophy' (Deleuze, 1994: p. 8).

What does this notion of theatre involve? It is a peculiar term in that it simultaneously refers to a very particular architecture (a building, a stage, a space within a space), a set of objects (masks, costumes, props), and a set of cultural practices (to act, to direct, to script). What we find in the citation above is thus a very deliberate use of the word 'theatre,' the construction of a specific architecture within philosophy where the interconnected frames of the theatre (the building, the stage, the auditorium) allow for philosophy to differentiate and become-other to itself, and to make available to us pure forces that link us 'directly with nature and history, with a language which speaks before words, with gestures which develop before organised bodies, with masks before faces, with spectres and phantoms before characters' (Deleuze, 1994: p. 10). It is the architecture of the theatre that sets its actors in motion and effectively allows Kierkegaard and Nietzsche to delineate the concepts of a new philosophy of difference. It is clear that this involves both architecture and characters, spatiality and personae, but the architecture it involves is specifically that of a theatre - it is not the house, it is not domesticity - and the characters are not literary figures but dramatic ones. 'This is our true theatre,' Deleuze writes, 'we are not speaking of the effort of the actor who "repeats" because he has not yet learned the part. We have in mind the theatrical space, the emptiness of that space, and the manner in which it is filled and determined by the signs and masks through which the actor plays a role which plays other roles' (Deleuze, 1994: p. 10).

Philosophy needs theatre in the same way that writing needs architecture: to liberate a potential for differentiation. To Deleuze and Guattari, however, they operate along different vectors. Whereas art, including writing, proceed through aesthetic figures - Melville's Bartleby, Kafka's Gregor, Beckett's Molloy - philosophy proceeds through conceptual personae - Nietzsche's Zarathustra, Kierkegaard's Job, Descartes' idiot; whereas an aesthetic figure is set in motion in relation to an architecture - consider the relevance of the office for Bartleby, or the bedroom for Gregor - conceptual personae operate through drama, masks and costumes, theatre. This is a distinction Deleuze and Guattari insist upon throughout their work: Art and philosophy operate along different vectors, and conceptual personae and aesthetic figures are distinct from one another. In relation to an architecture, aesthetic figures create affects; in relation to theatre, conceptual personae create concepts (Deleuze and Guattari, 1994: p. 66). ${ }^{\text {vi }}$

We now arrive at the second aspect of the question: how does one begin to write? For Deleuze and Guattari, writing involves an architecture, but also an expression without content. Whereas philosophy creates concepts, writing proceeds 
through affects, or better the expression of affects (the affect, as it were, being 'the expressed' of the expression). Discussing cinema rather than literature, Deleuze clearly both distinguishes between and links affect and expression. 'It is something expressed', he writes about the affect, 'it does not exist independently of something which expresses it, although it is completely distinct from it' (Deleuze, 2013: p. 110). This is not specific to cinema. In as much as writing has to do with wresting the affect from an encounter it necessarily involves expression. It is precisely this relationship between the encounter, the affect, and the expression that Deleuze hints at in Cinema I where he writes that the affect 'is independent of all determinate space-time; but it is none the less created in a history which produces it as the expressed and the expression of a space and a time, of an epoch or a milieu (this is why the affect is the 'new' and new affects are ceaselessly created, notably by the work of art) (Deleuze, 2013: p. 110)'. In their book on Kafka, Deleuze and Guattari develops this notion of expressivity making a crucial distinction between a major literature which proceeds from a predetermined content given its appropriate literary expression - the content, here, precedes the expression - and a minor literature, such as Kafka's, in which an affective encounter sets in motion a writing machine capable of expressing affects - expressions without content - that disorganise dominant regimes of expression and content and themselves do not 'conceptualise until afterwards' (Deleuze and Guattari, 1986: p. P. 28). It is, in other words, a kind of writing that proceeds from the materiality of language, from its affective register, pregnant with expressions capable of destabilising and disorganising syntactical language. This is a significant distinction. An affect involves a passage between affections, but a writer does not simply re-present an affection - a state of being - in literary form. The kind of literature that simply provides an affection with a literary expression is precisely the kind of generic literature Deleuze and Guattari oppose: a literature of lived experiences, Oedipal subjects of conjugal contracts, pre-given concepts, and habitual forms of thought and their corresponding knowledges. Other kinds of writing, however, have to do with wresting the affect from the affection in an expression without pre-determined content. Another way of putting it is perhaps to say that whereas major literature, to Deleuze and Guattari, simply states that somebody stutters, whispers or screams (a content given a generic literary expression), a minor literature makes language itself stutter, whisper or scream (an expression without content, language's affective register) (see also Deleuze, 1998: p 108). ${ }^{\mathrm{vii}}$

Again, this is precisely Deleuze and Guattari's take on Kafka - where language, they write, 'stops being representative in order to now move to its extremities or its limits' (Deleuze and Guattari, 1986: p. 23). It is also manifest to an even greater degree in Deleuze's Essays Critical and Clinical. Drawing upon a diverse range of figures, it is clear from several of the essays collected in this volume that Deleuze resolutely foregrounds an 'affective and intensive language' (Deleuze, 1998: p. 107) that screams, stutters, stammers or murmurs in what he refers to as a 'music proper to [...] poetry’ (Deleuze, 1998: p. 173). This, to Deleuze, is language's becoming-other or, better perhaps, becoming-minor.

It is not, however, to irrevocably separate the affective register of language from its syntactical regimes. In Kafka: Toward a Minor Literature it is clearly the case that an expression without content, an affect, destabilises or disorganises syntactical language, but it is equally clear that it eventually conceptualises and generates forms of content and expression within syntactical language. Similarly, in Essays Critical and Clinical, it is consistently in relation to maternal language - the architecture of domesticity - that the becoming-other of language begins to function, albeit only to open up to the invention of a new, foreign language within the syntactical regimes of maternal language.

[Literature] opens up a kind of foreign language within language [...] a becoming-other of language, a minorization of [a] major language, a delirium that carries it off, a witch's line that escape the dominant system. [...] So literature already presents two aspects: through the creation of syntax, it brings about not only a decomposition or destruction of the maternal language, but also the invention of a new language within language (Deleuze, 1998: p. 5).

The wording is significant here: the foreign within the maternal, 'the becoming-other of language.' 'The maternal' has little to do with 'woman.' It is, in fact, contrary to 'woman' in the sense that Deleuze and Guattari use the notion 'woman' to connote a certain - minoritarian - relationship to power and dominance (see, for instance, Guattari, 1996b: pp. 40-44). The maternal is rather to be considered the domestic, the soil, the fundament of colere and oikos [oĩkos]. Similarly, the foreign, the writer as a 'foreigner in his own language' (Deleuze, 1998: p. 110) is not necessarily a person 
who speaks in another's native tongue. 'A great writer,' Deleuze insists, 'is always like a foreigner in the language in which he expresses himself, even if this is his native tongue' (Deleuze, 1998: p. 109). Rather, the foreign is the potential of maternal language, the language of domesticity, the home and the soil, to become-other to itself. It is not 'outside of language' but 'the outside of language [my italics]' (Deleuze, 1998: p. 5). An outside contained within as a potential for language to become-other to itself (Deleuze, 1998: p. 110) in a continuous process of differentiation.

In what does writing begin? In the affect-constellations that make up the encounters of a life, in a slowing down or a speeding up, wtih rises and falls in intensity. Deleuze and Guattari brings us close to a materialist theory of aesthetic experimentation. Or rather, they conflate a materialist - Spinozist - theory of affect with a notion of creativity grounded

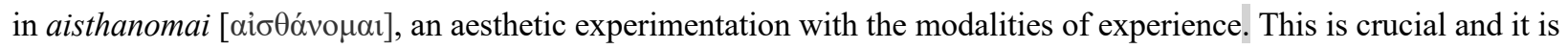
what distinguishes the writing practice I would like to propose here from literature in a more generic sense. Affects are intrisically expressive, but these expressions without content are incapacitated in dominant literatures, leaving maternal language intact along with its literary genres and conventions. In the kind of writing practice I have in mind, following Deleuze and Guattari, they instead function virally destabiling maternal language and opening out onto differentiation and new conceptualisations.

How does one begin to write? By the means of an architecture and an expression without content; a house and a trajectory of escape; a territory and a line of flight. Writing begins in the affect-constellation of an encounter, but one begins to write by wresting the affects from that encounter in an expression without content, and, significantly, by turning that encounter into a writing practice. However, just as an entire micro-physics of affects is required for a writing machine to be assembled and set in motion; just as writing emerges, in part, from other affect-constellations than those that determine an ethico-political program or those from which knowledge emerges, we also need to consider the notion of architecture and theatre, aesthetic figures and conceptual personae, affect and concept, as only relatively distinct. In other words, we need to rethink the distinction Deleuze and Guattari tend to maintain between philosophical thought and artistic practice, and open up, instead, to the notion that transversal lines may cross between these fields in practices that are creative and critical, that involve aesthetic figures and conceptual personae, affects and concepts, architecture and theatre, and significantly, that may transgress such dichotomies altogether producing exceedingly hybrid forms. Perhaps it is precisely in such contamination of the one with the other, that we find a further potential for deterritorialisation. The contamination of ethico-politics with aesthetics and vice versa; the contamination of architecture - the house - with theatre, and of theatre with architecture; the contamination of affects and concepts by their juxta- and superimposition and by trajectories constantly criss-crossing between them - the affect of concept, the concept of affect. ${ }^{\text {viii }}$ And the examples brought up here by no means exhaust the potentials of such practice of contamination. What role does performance play in a writing practice? What transversal lines of deterritorialization can be drawn between philosophy, writing and performance, or between writing, music and film, or between art history and fiction? How can the territorialities that fix writing to the conventional notions of book (or, indeed, journal) production and typography be undone, and what lines of flight can emerge from the undoing of such conventions? Trying to conceive of a creative critical writing practice beyond literature, one which is non-literary despite being, in part, lodged within literature, these are significant questions to ask ourselves. In fact, Deleuze and Guattari suggests as much in a passage in What is Philosophy?

This does not mean that [art and philosophy] do not often pass into each other in a becoming that sweeps them both up in an intensity which co-determines them. [...] It is as if, between them, not only alliances but also branchings and substitutions take place. [...] This means that the concept as such can be concept of the affect, just as the affect can be affect of the concept. [...] These thinkers are "half" philosophers but also much more than philosophers. [...] To be sure, they do not produce a synthesis of art and philosophy. They branch out and do not stop branching out. They are hybrid geniuses who neither erase nor cover over differences in kind but, on the contrary, use all the resources of their "athleticism" to install themselves within this very difference, like acrobats torn apart in a perpetual show of strenght (Deleuze and Guattari, 1994: pp. 66-67). 
Hybrids, branchings, bifurcations, transversals. An athleticism of contamination and impurity. In many ways, such transversality is characteristic of Deleuze and Guattari's earlier collaborations, on either side of the Kafka book. AntiOedipus (1984) and A Thousand Plateaus (1988) are works that in many ways proceed precisely through such peculiar athleticism. Nevertheless, this is not how they generally see art, literature or philosophy working, at least not in the majority of What is Philosophy? Instead, they consistently and firmly place the emphasis on demarcating distinct practices, irreducible to one another. Only reluctantly and cautiously do they open up to lines of flight or deterritorialization that would actually traverse these fields, contaminating them while rendering them pregnant with precisely the potential they ascribe to deterritorializations within each specific form of art or within philosophical thought itself. However, we do find these passages scattered here and there in Deleuze and Guattari's later work. They are, perhaps, hesitations, or brief acknowledgments that their concepts might themselves open up to a mutagenetic potential sending them off along a witch's line of flight traversing, in this case, the divides and boundaries between literature, art and philosophy. Nonliterary creative critical writing, in the expanded sense proposed here, might be one of the places where this twisting line of flight turns out to become an expressive one.

\footnotetext{
${ }^{\text {i }}$ Deleuze and Guattari's Kafka is significantly not a writer in the sense of an author publishing works of literature in recognisable genres and formats. Rather, they treat him like a writing machine, continuously expressive, continously encountering impossibilties new lines of flight, criss-crossing perpetually between the different components of his literary assemblage - the letters, the stories, the novels - in a process seemingly interminable (see Deleuze and Guattari, 1986: pp, 40-41).

ii It is worth noting, however, that to Deleuze and Guattari the relative speeds from which such vibration is composed spring from an 'absolute state of movement as well as of rest [my italics]' (Deleuze and Guattari, 1988: pp. 267) and that reaching such absolute state by means of deterritorialization involves complex relations of speeds and slownesses. This is foregrounded both in $A$ Thousand Plateaus (see Deleuze and Guattari, 1988: pp. 56, 174) and in Deleuze's short essay Spinoza and the Three Ethics (Deleuze, 1998: pp. 139-142). In the latter, Deleuze even speaks of an 'ambiguous' affect that 'increases and diminishes our power at the same time' (Deleuze, 1998: p. 140). It is, in other words, a question of complex constellations of affects and although the ethics we find in Spinoza is grounded in our capacity to distinguish those affects that diminish our capacity from those that increase our capacitiy, between increasing and decreasing speeds, the aesthetic Deleuze and Guattari read into Spinoza involves both speeds and slownesses.

${ }^{i i i}$ For an insight into Deleuze's take on Spinoza's epistemology see Deleuze, 1988: pp. 48-51, 81-83 and Deleuze, 1992: pp. $273-288$. For a discussion of Deleuze's take on Spinoza's ethico-politics, see Deleuze, 1992: pp. 255-272.

${ }^{\text {iv }}$ It should be noted that this is a collection of essays by Deleuze written between 1970 and 1993. It cannot be considered a homogenous statement on literature in the same sense as Deleuze and Guattari's book on Kafka. However, as Daniel W. Smith suggests in the introduction to the collection, a series of concepts and motifs 'appear and reappear in different essays [and in] increasingly complex contrapuntal relationships with each other' (Deleuze, 1998: p. xiii). What is being proposed here is that some of these concepts and motifs, alongside the motifs that appear in Kafka: Toward a Minor Literature, open up to a conception of a creative critical writing practice outside of the conventions of literature.

${ }^{v}$ Deleuze is beginning to make these distinctions. He emphasises, for instance, how these aesthetic encounters leave the writer profoundly exhausted. In the pages of Essays Critical and Clinical, Deleuze ceaselessly insists on the tiredeness, the exhaustion, the fragility of the writer who 'returns from what he has seen and heard with blood-shot eyes and pierced eardrums' (Deleuze, 1998: $p$. $3)$.

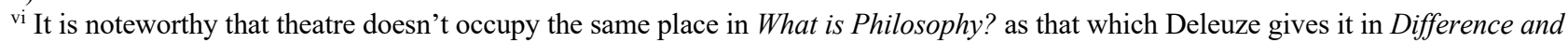
Repetition. Nevetheless, there is something intrinsically dramatic about the conceptual personae in Deleuze and Guattari's work that dinstinguishes them from aesthetic figures; a sense of performance, play-acting, and a sense of the actor's delivery of a line, as opposed to the relative muteness of the aesthetic figures which are not characters at all but parts of sensory landscapes.

vii The affective register of language is clearly also crucial to Guattari, who links it more directly to questions of subjectivity and subjectification. It is affects that open up to the ethico-aesthetic processes of subjectification that remain so central in his writing and to his practice. See for instance, Guattari (1995a).

viii In a striking passage at the end of What is Philosophy?, Deleuze and Guattari returns to this issue referring to 'interferences' (Deleuze and Guattari, 1994: p. 216) between disciplines and the co-dependency of art and nonart, philosophy and nonphilosophy, science and nonscience. It is within this realm of interference - what I have called contamination - that I believe a nonliterary space opens up for writing (see Deleuze and Guattari, 1994: pp. 216-218).
} 
References:

Deleuze, G (1988) Spinoza: Practical Philosophy (First Edition). San Francisco: City Light Books.

Deleuze, G (1992) Expressions in Philosophy (Third Erinting). New York: Zone Books.

Deleuze, G (1994) Difference and Repetition (Second Edition). London: Athlone Press.

Deleuze, G (1998) Essays Critical and Clinical (First Edition). London: Verso.

Deleuze, G, (2006) Two Regimes of Madness: Texts and Interviews 1975-1995 (First Edition). New York: Semiotext(e).

Deleuze, G (2013) Cinema I: The Movement-Image (First Edition). London: Bloomsbury Academic.

Deleuze, G and Guattari, F (1984) Anti-Oedipus: Capitalism and Schizophrenia (Fourth Edition). London: The Athlone Press.

Deleuze, G and Guattari, F (1986) Kafka: Toward a Minor Literature (Sixth Printing). Minneapolis: University of Minnesota Press.

Deleuze, G and Guattari, F (1988) A Thousand Plateaus: Capitalism and Schizophrenia (Third Edition). London: The Athlone Press.

Deleuze, G and Guattari, F (1994) What is philosohy? (First Edition). London: Verso.

Grosz, E (2008) Chaos, Territory, Art: Deleuze and the Framing of the Earth (First Edition). New York: Columbia University Press. Guattari, F (1995a) Chaosmosis: An Ethico-Aesthetic Paradigm (First Edition). Sydney: Power Publications.

Guattari, F (1995b) On Machines. Journal of Philosophy and the Visual Arts (6): 8-12.

Guattari, F (1996a) Becoming-Woman. In: Lotringer, S (ed) Soft Subversions. New York: Semiotext(e).

Guattari, F (1996b) A Liberation of Desire: An Interview with George Stambolian. In: Genosko, G (ed) The Guattari Reader.

Oxford: Blackwell Publishers.

O'Sullivan, S (2006) Art Encounters Deleuze and Guattari: Thought Beyond Representation (First Edition). New York: Palgrave MacMillan.

Spinoza, B (2002) Ethics. In: Morgan, M L (ed) Spinoza: Complete Works. Indianapolis: Hackett Publishing Company. 